\title{
Endoscopic management of acute anastomotic leakage after low colorectal anastomosis with cyanoacrylate bioglue (Glubran 2)
}

Although acute anastomotic leakage following low anterior resections occurs at a significant rate (up to $15 \%$ of cases), and represents a major cause of morbidity and mortality, there is no general consensus among surgeons and endoscopists on how best to treat it. In cases of high-flow peritoneal leak, surgery is the only choice; but for low-flow leaks, which lead to abscess formation, there are many different options, including minimally invasive treatment choices such as endoscopic clips (like over-thescope clips) to close the internal ostium of the fistula, stenting, or the use of tissue glues such as fibrin or cyanoacrylate sealants.

Compared with fibrin sealants, cyanoacrylate glues have the advantage of working well in wet environments and also have antibacterial properties, making them useful for contaminated sites. Generally, endoscopic debridement is needed beforehand. Following application of the bioglue, a strong foreignbody reaction sets in, promoting tissue healing, and within 10-15 days the bioglue clot falls off [1].

More recent data have shown the safety and efficacy of cyanoacrylate instillation for management of gastrointestinal anastomotic leakage [2,3], although there are no controlled series with colorectal anastomosis. All authors recommend cyanoacrylate instillation for fistulas with small openings, and advise that repeated instillations may be necessary to ensure fistula obliteration - as also happened in the case we report.

It should be noted that it is undesirable to completely fill the cavity with cyanoacrylates, especially in medium-to-large abscesses or long fistula tracts, as this can lead to chronic sinus formation; the recommendation is to seal only the internal ostium of the fistula [1], or to perform combined obliterations using fibrin sealants to fill the cavity and fistula tract

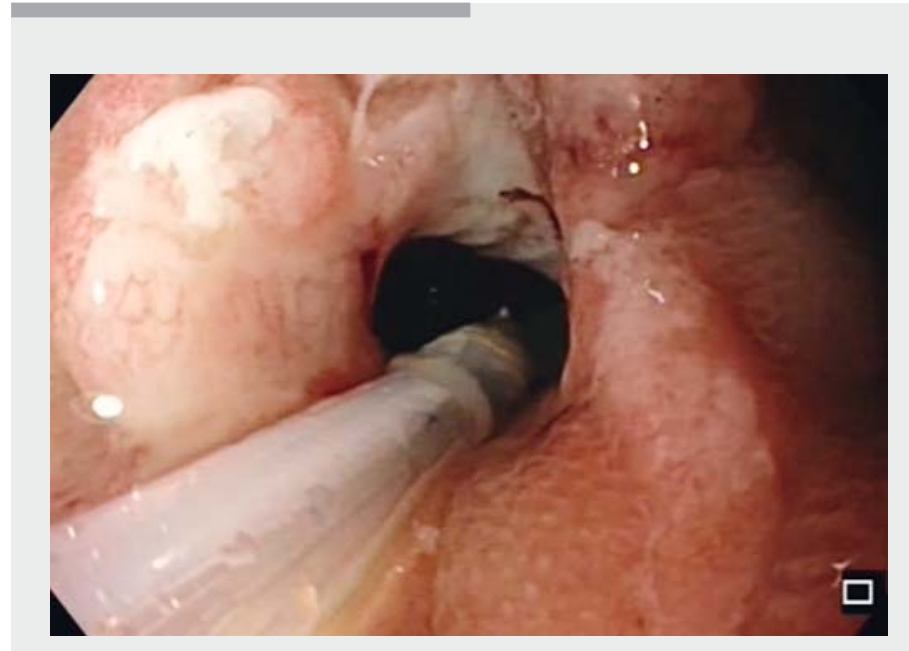

Video 1 A case of acute anastomotic leakage following low colorectal anastomosis managed endoscopically using cyanoacrylate bioglue to seal the fistula tract.

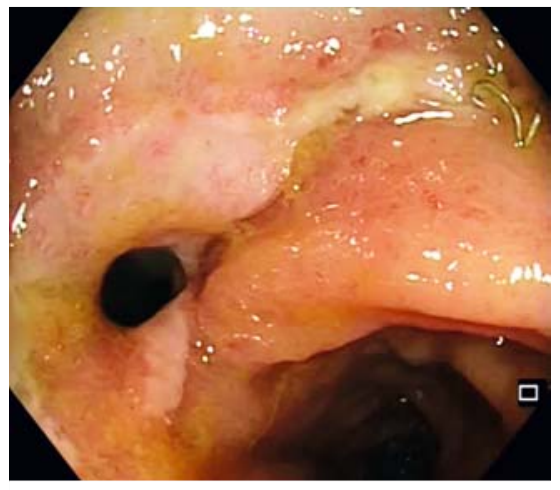

Fig. 1 Colorectal anastomosis with internal opening of a fistula.

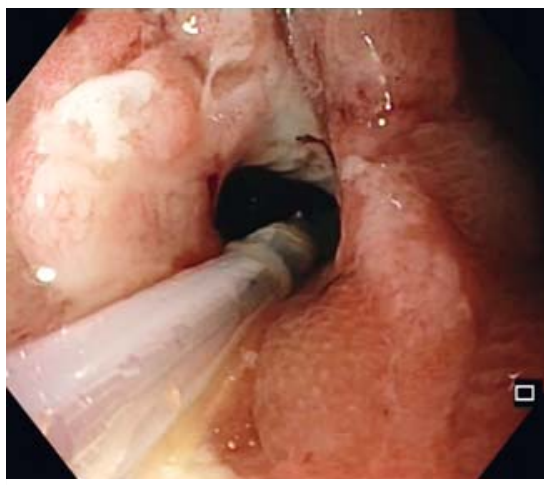

Fig. 2 Instillation of cyanoacrylate sealant.

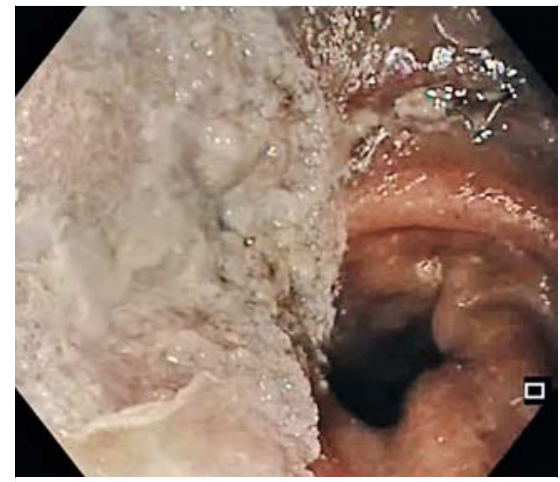

> Fig. 3 Cyanoacrylate clot.

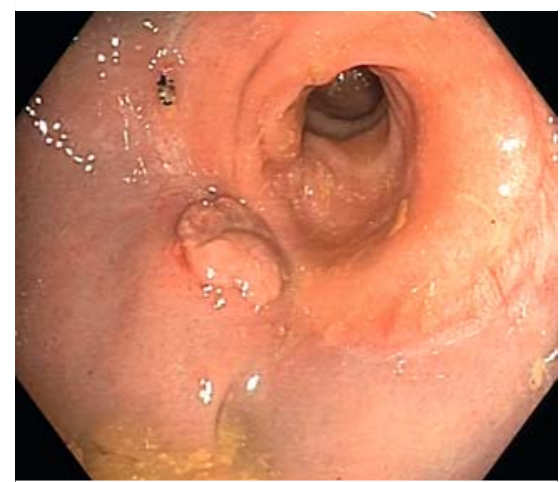

Fig. 4 Healed anastomosis with remaining granuloma over the former ostium of the fistula. 
and cyanoacrylates to close the internal ostium [2].

In some cases when percutaneous drainage of an abscess is performed with a persistent fistula tract, cyanoacrylates can also be instilled through the catheter to fill the cavity and fistula tract $[4,5]$, enabling a combined percutaneous - endoscopic approach.

We present a case of acute anastomotic leakage following low colorectal anastomosis ( $\triangleright$ Video 1 ) with fully endoscopic management, including confirmation of the diagnosis ( $\triangleright$ Fig. 1 ), closure of the fistula tract with cyanoacrylate bioglue in two consecutive instillations ( $>$ Fig. 2 , - Fig.3), and subsequent healing of the anastomosis within 15 days ( $\mathbf{F i g} \mathbf{4}$ ).

Endoscopy_UCTN_Code_TTT_1AQ_2AG

\section{Competing interests}

The authors declare that they have no conflict of interest.

\section{The authors}

Diego Ramos ${ }^{1}$, Enrique Vázquez-Sequeiros ${ }^{2}$, Pedro Abadía', Juan D. Pina ${ }^{1}$, Irene Moreno', Javier Die Trill ${ }^{1}$, Juan C. García Pérez ${ }^{1}$

1 Colorectal Surgery Division, General and Visceral Surgery Department, Ramon y Cajal University Hospital, Madrid, Spain

2 Gastroenterology and Endoscopy Department, Ramon y Cajal University Hospital, Madrid, Spain

\section{Corresponding author}

\section{Diego Ramos, MD}

Colorectal Surgery Division, Ramon y Cajal University Hospital, Ctra. Colmenar Viejo, km 9100, 28034 Madrid, Spain diego.ramos.rubio@gmail.com

\section{References}

[1] Singer AJ, Thode HC Jr. A review of the literature on octylcyanoacrylate tissue adhesive. Am J Surg 2004; 187: 238-248

[2] Kotzampassi K, Eleftheriadis E. Tissue sealants in endoscopic applications for anastomotic leakage during a 25-year period. Surgery 2015; 157: 79-86

[3] Rotondano G, Viola M, Orsini L et al. Uncommon cause of early postoperative colonic fistula successfully treated with endoscopic acrylate glue injection. Gastrointest Endosc 2008; 67: 183-186
[4] Nunes TF, de Santi GF. Percutaneous embolization of a colonic fistula using $n$-butyl- 2 cyanoacrylate (Histoacryl). Tech Coloproctol 2017; 21: 763-765

[5] Musa N, Aquilino F, Panzera P et al. Successful conservative treatment of enterocutaneous fistula with cyanoacrylate surgical sealant: case report. G Chir 2017; 38: 256259

\section{Bibliography}

Endoscopy 2021; 53: E136-E137

DOI 10.1055/a-1216-0861

ISSN 0013-726X

published online 5.8 .2020

(c) 2020. Thieme. All rights reserved.

Georg Thieme Verlag KG, Rüdigerstraße 14,

70469 Stuttgart, Germany

\section{ENDOSCOPY E-VIDEOS}

https://eref.thieme.de/e-videos

回回 Endoscopy E-Videos is a free

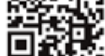
access online section, reporting on interesting cases and new

techniques in gastroenterological endoscopy. All papers include a high quality video and all contributions are freely accessible online.

This section has its own submission website at https://mc.manuscriptcentral.com/e-videos 